\title{
An innovative method to enhance protease tolerance of nisin in endogenous proteases
}

\author{
Dan Pan, ${ }^{1}$ (1) Limin Hao, ${ }^{2}$ Jingjing Li, ${ }^{1}$ Juanjuan Yi, ${ }^{1}$ Qiaozhen Kang, ${ }^{1}$ Xin Liu, ${ }^{1}$ Laizheng Lu, ${ }^{3}$ and Jike Lu ${ }^{1 *}$ (]) \\ ${ }^{1}$ School of Life Sciences, Zhengzhou University, Zhengzhou, Henan, 450001, China \\ ${ }^{2}$ The Quartermaster Research Institute of Engineering and Technology, Academy of Military Sciences PLA China, Beijing 100010, China \\ ${ }^{3}$ Zhengzhou Mindtek Biological Co. Ltd., Zhengzhou, Henan, 450001, China
}

\begin{abstract}
Nisin, a natural peptide produced by Lactococcus lactis cultivation in milk whey, is widely used as a preservative in industrial production. However, nisin can be degraded by endogenous enzymes in foods. In this study, we investigated the antibacterial activity of nisin-soybean protein and nisin-egg white protein and compared them with that of free nisin in cantaloupe juice, which was used as a model of endogenous protease environment. Results showed that endogenous proteases in the model resulted in a loss of nisin activity, but combining nisin with protein (soybean or egg white) resulted in greater protection of its antimicrobial activity by inhibiting endogenous proteases. The microbial addition experiment (Staphylococcus aureus and Micrococcus luteus) and preservation experiment in the food model showed that the antibacterial activity of nisin combined with either of the 2 proteins was higher than that of nisin alone in an endogenous protease environment. In summary, soybean protein and egg white protein improved the protease tolerance of nisin, expanding the application scope of nisin in food.
\end{abstract}

Key words: nisin, protease tolerance, soybean protein, egg white protein

\section{INTRODUCTION}

Nisin, a peptide produced by fermentation with milk as medium, exhibits wide antibacterial activity to gram-positive and pathogenic bacteria (e.g., Staphylococcus aureus, Listeria monocytogenes, and Clostridium botulinum; Pawar et al., 2000; Jozala et al., 2015; Ko et al., 2015). Therefore, nisin plays an important role in the field of food preservation (Abdollahzadeh et al., 2014). Nisin and cinnamaldehyde have showed synergistic inhibition of Staph. aureus in pasteurized milk (Shi

Received August 4, 2019.

Accepted September 26, 2019.

*Corresponding author: ljk002004@163.com et al., 2017). Nisin has also been used as a preservative to control spoilage bacteria (e.g., Bacillus thuringiensis, Bacillus cereus, and Paenibacillus jamilae) in high-fat milk pudding and extend its shelf life (Oshima et al., 2014). However, the challenge in the application of nisin is that some loss of antimicrobial activity occurs due to various factors, such as the fat, protein, and $\mathrm{pH}$ of the food system and the temperature of product storage (Huot et al., 1996; Pawar et al., 2000; Aasen et al., 2003; Chollet et al., 2008). Moreover, nisin loses part of its activity in an environment with high content of endogenous proteases (Sarkar et al., 2016, 2017). These factors severely reduce the antibacterial efficiency of nisin.

To date, various methods have been used to maintain the antimicrobial stability of nisin. For example, a nanoprecipitation technique improved the stability of nisin at $\mathrm{pH} 5.0$ and its antibacterial activity (Chang et al., 2018). Similarly, the complexation of nisin with biopolymer (pectin) increased its stability in the presence of acid protease and trypsin (Gruskiene et al., 2017). Nisin-chitosan microcapsules had better antibacterial activity than free nisin and could extend the shelf life of small yellow croaker by 6 to $9 \mathrm{~d}$ (Wu et al., 2017). Some researchers have increased the solubility of ni$\sin 3$ to 5 times and enhanced its stability at higher temperature and under neutral or alkaline conditions by using site-directed mutagenesis (Yuan et al., 2004). Soluble soybean polysaccharide nanoparticles extend the antimicrobial activity of nisin and prolong the storage period of tomato juice (Luo et al., 2019). However, these methods do not specifically address the sensitivity of nisin to proteases, which affect its activity and limit its application in foods. Therefore, developing a simple and low-cost method to enhance the tolerance of nisin to protease is urgently needed in industrial production. Protecting nisin by inhibiting the activity of endogenous proteases is a novel method.

Melon has high content of endogenous proteases and is suitable as a food model for studying nisin stability. Many protease inhibitors come from natural resources. 
Soybean protein contains $2 \%$ protease inhibitor, and ovomucoid (11\% of egg white protein) is a typical protease inhibitor (Salman, 2011; Muranova et al., 2019). Considering that soybeans and eggs are common and cheap agricultural products, they are ideal protease inhibitors, with great potential for large-scale application. In the current study, the goal was to evaluate the protease tolerance of nisin combined with soybean or egg white protein in the environment of endogenous protease, and to expand its potential use in food. The microbial addition experiment (Staph. aureus and $M i$ crococcus luteus) and preservation experiment of the food model were conducted to validate the protease tolerance of nisin combined with 2 proteins. The overall hypothesis was that soybean protein or egg white protein would improve the protease tolerance of nisin by inhibiting endogenous proteases in industrial production, expanding the application scope of nisin in food.

\section{MATERIALS AND METHODS}

\section{Materials}

Fresh melons were purchased from an agricultural market. Nisin $(30 \%, 12,000 \mathrm{IU} / \mathrm{mg})$, soybean protein (food grade), egg white protein (food grade), and 2 microorganism strains (Staph. aureus and M. luteus) were provided by Zhengzhou Mindtek Biological Co. Ltd. (Zhengzhou, China). Other chemicals (analytical grade) were obtained from Beijing Dingguo Changsheng Biotechnology Co. Ltd. (Beijing, China).

\section{Preparation of Solutions}

Five different varieties of melon (Xiaobai melon, Huapi melon, Lvbao melon, Qingtian melon, and cantaloupe) were selected and used to produce fresh melon juice. Part of the melon juice was treated in a boilingwater bath for $10 \mathrm{~min}$ to inactivate the endogenous enzymes of melon juice for use in the heated melon juice treatment. For the preparation of other solutions, solid powder (nisin, soybean protein, or egg white protein) was weighed accurately and dissolved in $\mathrm{HCl}(\mathrm{pH} 7.5$, $0.02 \mathrm{~mol} / \mathrm{L})$.

\section{Activity of Nisin in Different Melon Juices}

Fresh and heated melon juices were reacted with nisin at an optimum concentration of $1.5 \mathrm{mg} / \mathrm{mL}$ using a $5: 1$ volume ratio (melon juice:nisin solution) at $4^{\circ} \mathrm{C}$ for $24 \mathrm{~h}$. The nisin titer was measured by agar diffusion assay with standard curve method (Holcapkova et al., 2018). Nisin activity (NA) was assessed as follows: NA $(\%)=\mathrm{NT}_{1} / \mathrm{NT}_{0} \times 100 \%$, where $\mathrm{NT}_{0}=$ titer of nisin alone (control, $\mathrm{IU} / \mathrm{mL}$ ) and $\mathrm{NT}_{1}=$ nisin titer of the treatment $(\mathrm{IU} / \mathrm{mL})$.

\section{Determination of Residual Enzyme Activity in the Cantaloupe Juice Model}

The cantaloupe juice was reacted with $37.5 \mathrm{mg} / \mathrm{mL}$ soybean protein or $5.769 \mathrm{mg} / \mathrm{mL}$ egg white protein solution at different ratios at $40^{\circ} \mathrm{C}$ for $1 \mathrm{~h}$. The endogenous enzyme activity (EA) of the model was measured according to the method of National Standard of China (2009; GB/T23527-2009). The residual enzyme activity of cantaloupe juice (RE) was evaluated as follows: $\mathrm{RE}$ $(\%)=\mathrm{EA}_{1} / \mathrm{EA}_{0} \times 100$, where $\mathrm{EA}_{0}$ was the protease activity of cantaloupe juice alone (control, $\mathrm{U} / \mathrm{mL}$ ) and $\mathrm{EA}_{1}$ was the protease activity of the treatment (U/ $\mathrm{mL})$.

\section{Effects of Proteins on Nisin Activity in the Cantaloupe Juice Model}

To study the effects of the 2 proteins on nisin activity in endogenous protease, different reaction solutions were prepared: (1) nisin solution (control); (2) a mixture of nisin solution and cantaloupe juice (CJ-N); (3) mixtures of nisin solution, cantaloupe juice, and soybean protein solution of different volumes (CJ-N-S); and (4) mixtures of nisin solution, cantaloupe juice, and egg white protein solution of different volumes (CJ-N-E). After all reactions were carried out at $4^{\circ} \mathrm{C}$ for $24 \mathrm{~h}$, the activity of nisin was measured.

\section{Growth of Microorganisms in the Cantaloupe Juice Model}

Culture of Microbial Strains. One milliliter of Staph. aureus or M. luteus was inoculated in BairdParker and nutrient agar media, respectively. Media were bought from Beijing Dingguo Changsheng Biotechnology Co. Ltd. (Beijing, China). After culturing at $33^{\circ} \mathrm{C}$ for $20 \mathrm{~h}$, microbial cells were used for the microbial addition experiment.

Treatment of Cantaloupe Juice Model. Cantaloupe juice model treatments were as follows: microorganism only $(\mathbf{M})$; microorganism and nisin added (M-N); microorganism, nisin, and soybean protein (M-N-S); and microorganism, nisin, and egg white protein (M-N-E). Finally, all samples were vacuum packed and stored at $4^{\circ} \mathrm{C}$. On d $0,1,2,4,6$, and 8 , samples were withdrawn and tested for colony-forming units of the microorganisms (Staph. aureus and M. luteus) by Baird-Parker plate counting method and the dilution coating method, respectively. 


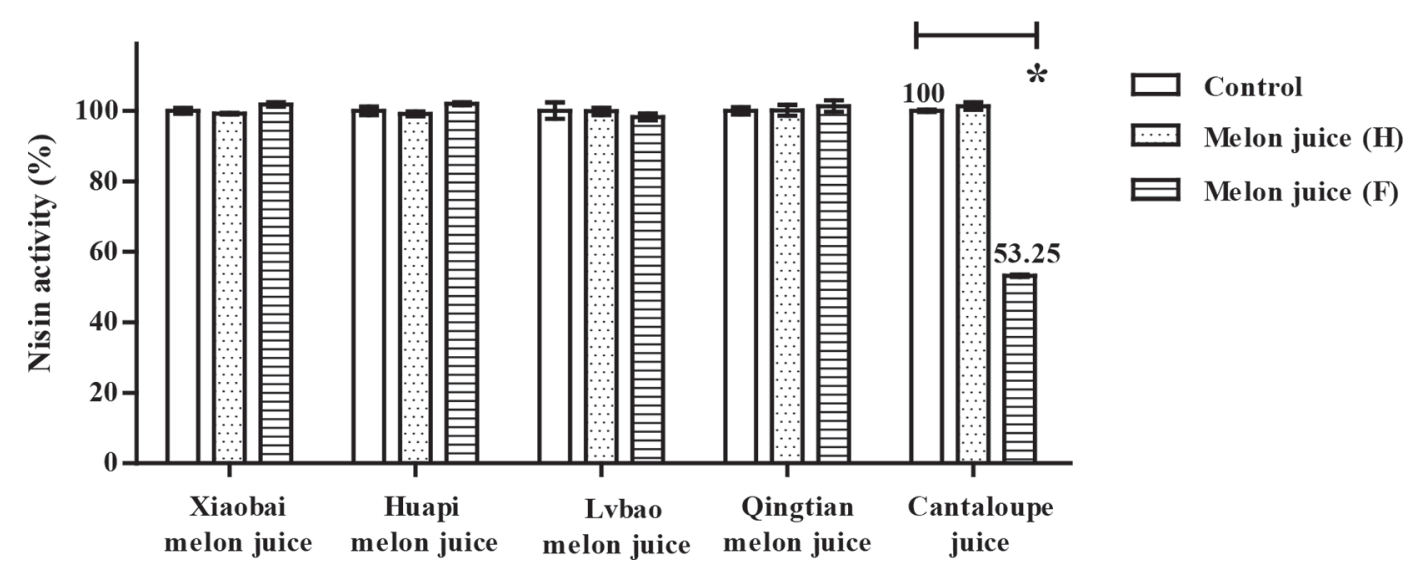

Figure 1. Changes in nisin activity (mean $\pm \mathrm{SD}$ ) in buffer solution (control), heated melon juice [melon juice $(\mathrm{H})]$, or fresh melon juice [melon juice $(\mathrm{F})]$ at $4^{\circ} \mathrm{C}$ for $24 \mathrm{~h}$. ${ }^{*}$ Significant differences compared with control group $(P<0.05)$.

\section{Antimicrobial Efficacy of Nisin with Protein in the Cantaloupe Juice Model}

Nisin was added to fresh cantaloupe juice (MG, control) at $0.002 \%$ for treatment MG-N. Soybean protein and egg white protein were added to the cantaloupe juice at $3 \%$ and $2 \%$ ratio for treatments MG-N-S and MG-N-E, respectively. After 0, 3, 6, and $9 \mathrm{~d}$ of storage at $4^{\circ} \mathrm{C}$, samples were tested for total viable counts ( TVC) by the method described in the National Standard of China (2010; GB4789.2-2010). The TVC of control and treatment groups of cantaloupe juice model $(\mathrm{cfu} / \mathrm{mL})$ were designated $T_{0}$ and $T_{1}$, respectively. The $T$ value was used to describe the stability of microbial growth as follows: $\mathrm{T}=\mathrm{T}_{1} / \mathrm{T}_{0}$.

\section{Statistical Analysis}

All experiments were performed in triplicate, and data are expressed as mean values \pm standard deviations with sample size $(\mathrm{n})=3$. Data analysis was performed by using GraphPad Prism 5.0 (GraphPad Software Inc., San Diego, CA). Significance of the difference between variables was tested by $t$-tests. Differences at $P<0.05$ were considered significant.

\section{RESULTS AND DISCUSSION}

\section{Selection of Food Model}

To investigate the effects of endogenous proteases in food on nisin activity, 5 different melon juices were selected and reacted with nisin. The changes of nisin activity in different melon juices are shown in Figure 1. Fresh cantaloupe juice significantly decreased the activity of nisin. When fresh cantaloupe juice was added to nisin solution at a 5:1 volume ratio (cantaloupe juice: nisin solution), the fresh cantaloupe juice decreased the activity of nisin to $53.25 \pm 0.45 \%$. These results were consistent with previous reports that endogenous enzymes in cantaloupe juice could reduce nisin activity (Sarkar et al., 2016, 2017). Cantaloupe juice contains many serine proteases, such as trypsin, which could disrupt the integrity of the nisin peptide chain by cutting at positions $\mathrm{Lys}_{12}, \mathrm{Asn}_{20}$, and $\mathrm{Lys}_{22}$ (trypsin; Chen et al., 1996; Slootweg et al., 2013). When nisin solution was reacted with juices of other species, no significant changes were observed. Therefore, cantaloupe juice with high protease activity could be used as a model to study the effect of soybean protein and egg white protein on the protease tolerance of nisin in an endogenous protease environment.

\section{Residual Enzyme Activity in a Food Model}

Cantaloupe juice contains a large number of endogenous enzymes that can reduce nisin activity. Soybean protein and egg white protein contain many protease inhibitors (Norioka et al., 2006; Salman, 2011). Therefore, these 2 proteins were chosen as protease inhibitors to study the effects on endogenous enzymes in food. The results are depicted in Figure 2. When soybean protein was added to the cantaloupe juice at a $1: 1$ volume ratio, protease activity was $81.59 \pm 1.49 \%$. After reacting with egg white protein at a 1:1 ratio, the protease activity was reduced to $96.48 \pm 0.54 \%$. With increasing amounts of soybean protein or egg white protein, the endogenous protease activity gradually decreased within the range of measurement. When the volume ratio of protein to cantaloupe juice was increased to $9: 1$, the endogenous protease activities were $65.91 \pm 0.49 \%$ (soybean protein) and $52.24 \pm 2.21 \%$ (egg white protein). Soybean protein contains 2 ma- 


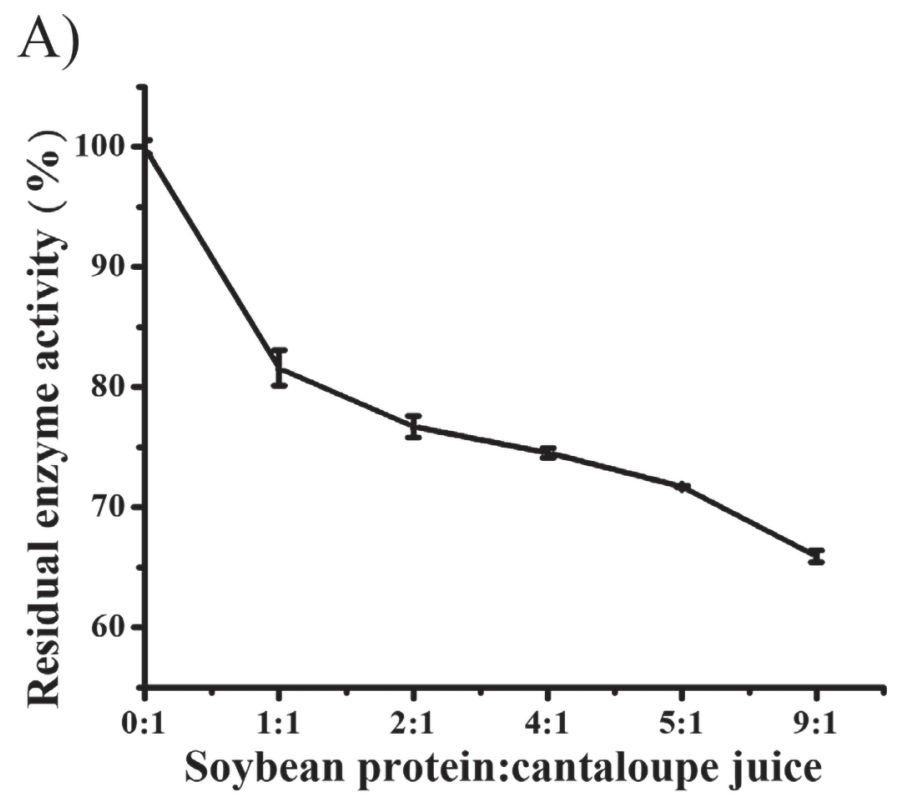

B)

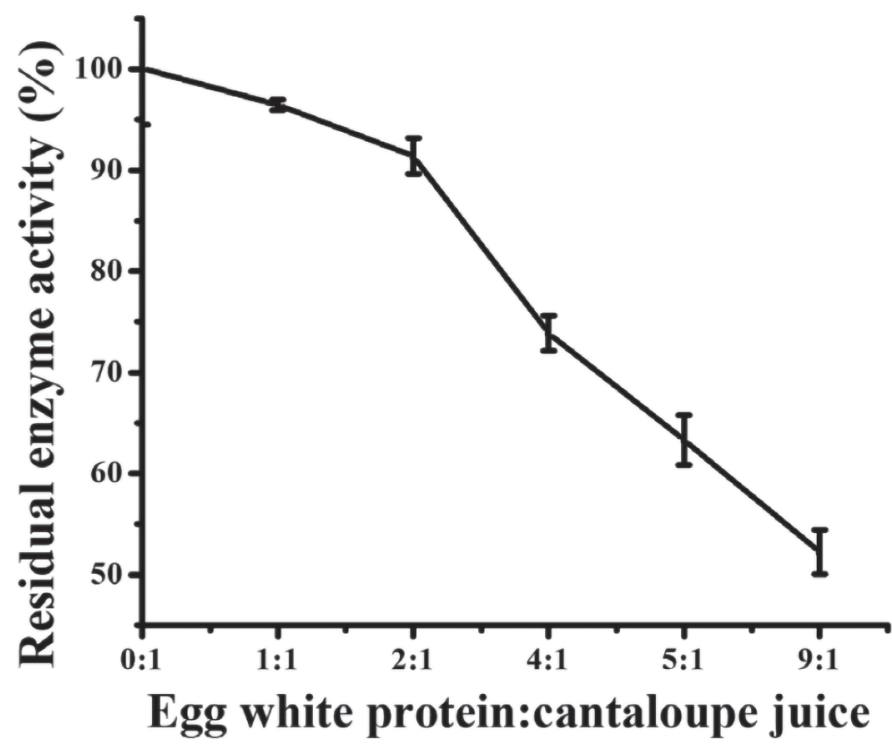

Figure 2. Changes in enzyme activity (mean $\pm \mathrm{SD}$ ) in cantaloupe juice model treated with soybean protein $(\mathrm{A})$ or egg white protein $(\mathrm{B})$. After $40^{\circ} \mathrm{C}$ for $1 \mathrm{~h}$, the residual enzyme activity in the cantaloupe juice model was measured. The $\mathrm{x}$-axis indicates the volume ratio of soybean protein or egg white protein to cantaloupe juice.

jor serine protease inhibitors, which account for about $6 \%$ of the total soybean protein content (Rackis et al., 1986; He et al., 2017). Ovomucoid in egg white protein is a widely known serine protease inhibitor, and $1 \mathrm{mg}$ of ovomucoid can inhibit the activity of $1 \mathrm{mg}$ of trypsin (Ødum, 1987). Protease inhibitors in soybean protein and egg white protein could degrade a part of endog- enous proteases in food. Therefore, we further studied the ability of the 2 proteins to protect nisin.

\section{Protection of Nisin by Proteins in Food Model}

Based on the inhibition of soybean and egg white proteins on endogenous protease, we further evaluated the effects of the 2 proteins on nisin activity (Figure 3). After nisin was reacted with cantaloupe juice in a 5:1 volume ratio (cantaloupe juice:nisin), the activity of nisin was reduced to $44.69 \pm 0.43 \%$. However, after adding soybean protein or egg white protein in a 5:1:1 volume ratio (cantaloupe juice:nisin:protein), the nisin activity was $69.20 \pm 0.89 \%$ and $61.49 \pm 0.39 \%$, respectively. In the range of determination, the activity of nisin gradually increased with increasing volumes of soybean protein or egg white protein. At a volume ratio of 5:1:3 (cantaloupe juice:nisin:protein), nisin activity was $82.01 \pm 0.78 \%$ (soybean protein) and 77.86 $\pm 1.41 \%$ (egg white protein). Thus, soybean protein and egg white protein inhibited endogenous protease activity in food and enhanced the protease tolerance of nisin. Soybean and egg white proteins could be used as protective agents to stabilize nisin activity in an endogenous enzyme environment.

\section{Changes in Microorganism Counts in Food Model}

To further verify the stabilization by soybean or egg white protein on nisin activity in the endogenous protease environment, we adopted a microorganism addition method. Staphylococcus aureus and M. luteus are gram-positive bacteria. Staphylococcus aureus is a major pathogen of dairy product contamination (Felicio et al., 2015) and M. luteus is widely used to study the antibacterial activity of nisin (Balasubramanian et al., 2011; Holcapkova et al., 2018). Changes in counts (cfu) of Staph. aureus and M. luteus during $8 \mathrm{~d}$ of storage are shown in Table 1 and Table 2.

In Table 1, the colony-forming units of Staph. aureus were significantly higher in group $\mathbf{M}(S)$ (control, $15 \%$ Staph. aureus added) than those in groups $\mathrm{M}(S)$ $\mathrm{N}, \mathrm{M}(S)-\mathrm{N}-\mathrm{S}$, or $\mathrm{M}(S)-\mathrm{N}-\mathrm{E}$ on $\mathrm{d} 0,1,2,4,6$, and 8 , reflecting nisin's antimicrobial property against Staph. aureus (Shi et al., 2017). Moreover, visible differences were present between group $\mathrm{M}(S)-\mathrm{N}$ and groups $\mathrm{M}(S)$ $\mathrm{N}$ and $\mathrm{M}(S)-\mathrm{N}-\mathrm{E}$; that is, the antibacterial activities of nisin-soybean protein and nisin-egg white protein were greater than that of nisin alone. Although endogenous enzymes in the food model could decrease the activity of nisin, soybean protein or egg white protein could improve the protease tolerance of nisin. These findings were in accordance with results shown in Figure 3. 
Table 1. Changes in count $\left(\mathrm{cfu} / \mathrm{mL} \times 10^{3}\right)$ of Staphylococcus aureus in the cantaloupe juice model

\begin{tabular}{|c|c|c|c|c|c|c|}
\hline Group $^{1}$ & \multicolumn{6}{|c|}{ Time (d) } \\
\hline $\begin{array}{l}\mathrm{M}(S) \\
\mathrm{M}(S)-\mathrm{N} \\
\mathrm{M}(S)-\mathrm{N}-\mathrm{S} \\
\mathrm{M}(S)-\mathrm{N}-\mathrm{E}\end{array}$ & $\begin{array}{r}6,030 \pm 1,960^{\mathrm{A}} \\
17.03 \pm 3.47^{\mathrm{B}, \mathrm{a}} \\
3.70 \pm 0.40^{\mathrm{B}, \mathrm{b}} \\
0.25 \pm 0.04^{\mathrm{B}, \mathrm{b}}\end{array}$ & $\begin{array}{l}9,800 \pm 4,840^{\mathrm{A}} \\
22.00 \pm 0.69^{\mathrm{B}, \mathrm{a}} \\
13.50 \pm 2.04^{\mathrm{B}, \mathrm{b}} \\
12.65 \pm 1.35^{\mathrm{B}, \mathrm{b}}\end{array}$ & $\begin{aligned} 16,670 & \pm 1,390^{\mathrm{A}} \\
0.81 & \pm 0.07^{\mathrm{B}, \mathrm{a}} \\
0.49 & \pm 0.05^{\mathrm{B}, \mathrm{b}} \\
0.37 & \pm 0.07^{\mathrm{B}, \mathrm{b}}\end{aligned}$ & $\begin{aligned} 5,100 & \pm 0^{\mathrm{A}} \\
1.07 & \pm 0.18^{\mathrm{B}, \mathrm{a}} \\
0.38 & \pm 0.08^{\mathrm{B}, \mathrm{b}} \\
0.28 & \pm 0.05^{\mathrm{B}, \mathrm{b}}\end{aligned}$ & $\begin{aligned} 24,870 & \pm 1,890^{\mathrm{A}} \\
3.66 & \pm 0.69^{\mathrm{B}, \mathrm{a}} \\
1.62 & \pm 0.41^{\mathrm{B}, \mathrm{b}} \\
0.17 & \pm 0.03^{\mathrm{B}, \mathrm{b}}\end{aligned}$ & $\begin{aligned} 6,800 & \pm 330^{\mathrm{A}} \\
1.20 & \pm 0.15^{\mathrm{B}, \mathrm{a}} \\
0.52 & \pm 0.14^{\mathrm{B}, \mathrm{b}} \\
0.23 & \pm 0.09^{\mathrm{B}, \mathrm{b}}\end{aligned}$ \\
\hline
\end{tabular}

The changes in colony-forming units of $M$. luteus are shown in Table 2. Group $\mathbf{M}(\boldsymbol{M})$, with $25 \%$ M. luteus added, had higher colony-forming units than groups $\mathrm{M}(M)-\mathrm{N}, \mathrm{M}(M)-\mathrm{N}-\mathrm{S}$, and $\mathrm{M}(M)-\mathrm{N}-\mathrm{E}$ on $\mathrm{d} 0,1,2,4$, 6 , and 8 , indicating that nisin inhibited the growth of $M$. luteus in the cantaloupe juice model (Fang et al., 2007). Significant differences were found between group $\mathrm{M}(M)-\mathrm{N}$ and groups $\mathrm{M}(M)-\mathrm{N}-\mathrm{S}$ and $\mathrm{M}(M)-\mathrm{N}-\mathrm{E}$, consistent with results in Figure 3. Although endogenous enzymes in the food model could affect the antibacterial activity of nisin, soybean or egg white protein could stabilize its antibacterial activity.

\section{Microbial Growth in Food Model}

In food preservation, change in TVC is an important parameter related to food freshness (Rahman et al., 2013). We used microbial growth in a cantaloupe juice model stored at $4^{\circ} \mathrm{C}$ to further demonstrate that the 2 proteins could enhance the protease tolerance of nisin and stabilize its antibacterial activity. The results of microbial growth are given in Figure 4. On d 0, the T values of group MG-N-S and MG-N-E were significantly lower than that of group MG-N. One likely reason was that different treatments had distinct effects on microorganism growth. During storage, the T value of group
MG-N gradually increased, and that of groups MG-N-S and MG-N-E remained lower. Soybean protein and egg white protein could influence the antimicrobial activity of nisin by inhibiting endogenous proteases. At the end of storage time, the $\mathrm{T}$ value of group $\mathrm{MG}-\mathrm{N}$ increased to $0.99 \pm 0.11$. For group MG-N-S and MG-N-E, the T values were only $0.03 \pm 0.03$ and $0.05 \pm 0.01$, respectively. These results further confirmed that soybean and egg white proteins improved the protease tolerance of nisin in the presence of endogenous proteases.

\section{CONCLUSIONS}

Soybean and egg white proteins enhanced the protease tolerance of nisin in endogenous proteases and prolonged the antibacterial activity of nisin. The endogenous proteases in cantaloupe juice model were responsible for the loss of nisin activity. When nisin was combined with soybean protein or egg white protein, the antibacterial efficacy of nisin was increased due to inhibition of the endogenous proteases. These results and preservation experiments of the food model further validated that the combination of nisin with protein could enhance the protease tolerance of nisin in an environment of endogenous proteases. Therefore, soybean protein and egg white protein could improve

Table 2. Changes in count $\left(\mathrm{cfu} / \mathrm{mL} \times 10^{2}\right)$ of Micrococcus luteus in the cantaloupe juice model

\begin{tabular}{|c|c|c|c|c|c|c|}
\hline Group $^{1}$ & \multicolumn{6}{|c|}{ Time $(\mathrm{d})$} \\
\hline $\begin{array}{l}\mathrm{M}(M) \\
\mathrm{M}(M)-\mathrm{N} \\
\mathrm{M}(M)-\mathrm{N}-\mathrm{S} \\
\mathrm{M}(M)-\mathrm{N}-\mathrm{E}\end{array}$ & $\begin{array}{r}29,700 \pm 5,900^{\mathrm{A}} \\
4.10 \pm 0.64^{\mathrm{B}, \mathrm{a}} \\
2.07 \pm 0.24^{\mathrm{B}, \mathrm{b}} \\
0.77 \pm 0.38^{\mathrm{B}, \mathrm{b}}\end{array}$ & $\begin{aligned} 35,300 & \pm 3,900^{\mathrm{A}} \\
10.30 & \pm 0.73^{\mathrm{B}, \mathrm{a}} \\
0.88 & \pm 0.04^{\mathrm{B}, \mathrm{b}} \\
1.96 & \pm 0.50^{\mathrm{B}, \mathrm{b}}\end{aligned}$ & $\begin{aligned} 68,300 & \pm 12,300^{\mathrm{A}} \\
4.04 & \pm 0.13^{\mathrm{B}, \mathrm{a}} \\
1.53 & \pm 0.25^{\mathrm{B}, \mathrm{b}} \\
0.65 & \pm 0.02^{\mathrm{B}, \mathrm{b}}\end{aligned}$ & $\begin{aligned} 75,300 & \pm 8,000^{\mathrm{A}} \\
3.87 & \pm 0.24^{\mathrm{B}, \mathrm{a}} \\
0.65 & \pm 0.12^{\mathrm{B}, \mathrm{b}} \\
0.23 & \pm 0.05^{\mathrm{B}, \mathrm{b}}\end{aligned}$ & $\begin{aligned} 145,000 & \pm 26,900^{\mathrm{A}} \\
3.85 & \pm 0.19^{\mathrm{B}, \mathrm{a}} \\
1.30 & \pm 0.04^{\mathrm{B}, \mathrm{b}} \\
0.29 & \pm 0.15^{\mathrm{B}, \mathrm{b}}\end{aligned}$ & $\begin{aligned} 260,000 & \pm 45,400^{\mathrm{A}} \\
3.66 & \pm 0.69^{\mathrm{B}, \mathrm{a}} \\
2.01 & \pm 0.37^{\mathrm{B}, \mathrm{b}} \\
0.17 & \pm 0.03^{\mathrm{B}, \mathrm{b}}\end{aligned}$ \\
\hline
\end{tabular}


A)

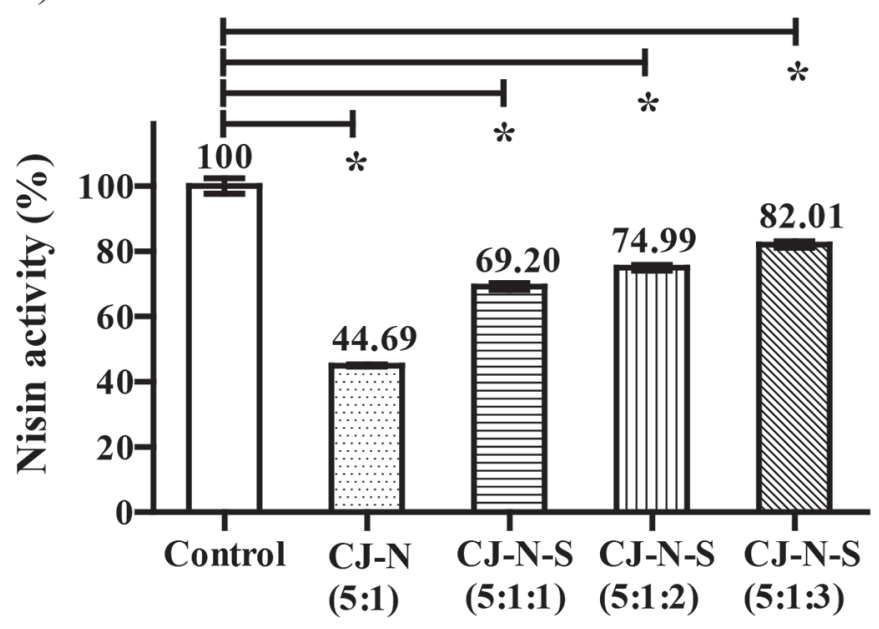

B)

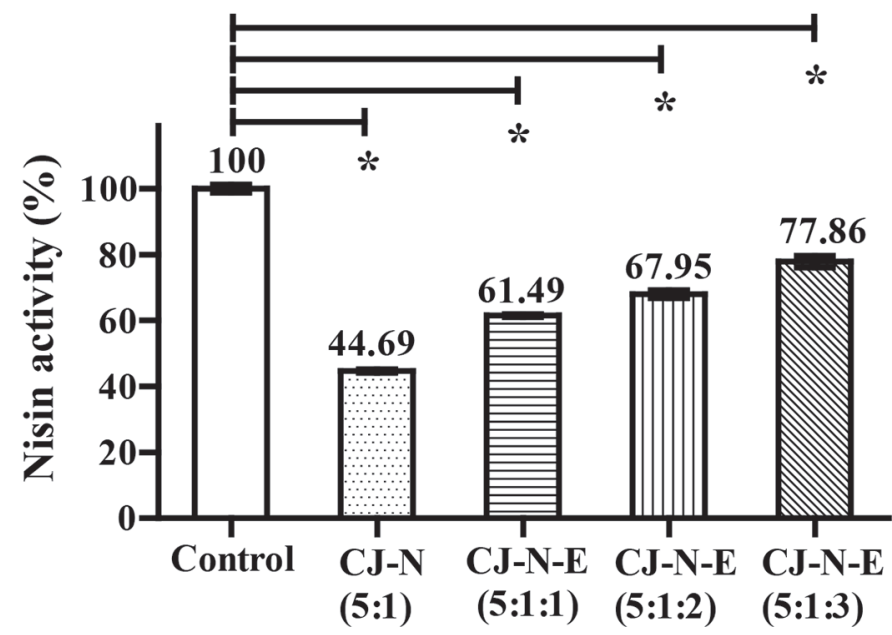

Figure 3. Protection of nisin (mean $\pm \mathrm{SD}$ ) by $(\mathrm{A})$ soybean protein or (B) egg white protein in an endogenous protease environment. Nisin was treated with buffer solution (control), cantaloupe juice (CJ-N), cantaloupe juice combined with soybean protein (CJ-N-S), or cantaloupe juice combined with egg white protein (CJ-N-E) at $4^{\circ} \mathrm{C}$ for 24 h. ${ }^{*}$ Significant differences compared with control group $(P<0.05)$.

the protease stability of nisin and expand the industrial application of nisin in high-protease environments.

\section{ACKNOWLEDGMENTS}

This work was supported by the National Natural Science Foundation of China (81571526, 81870093), the Research Project of People's Liberation Army (BX115C007), the Henan Provincial Science and Technology Innovation Outstanding Youth Support Program (184100510019), the Special Subject Funding of Zhengzhou University, and the Training Project for Young Outstanding Teachers of University in Henan

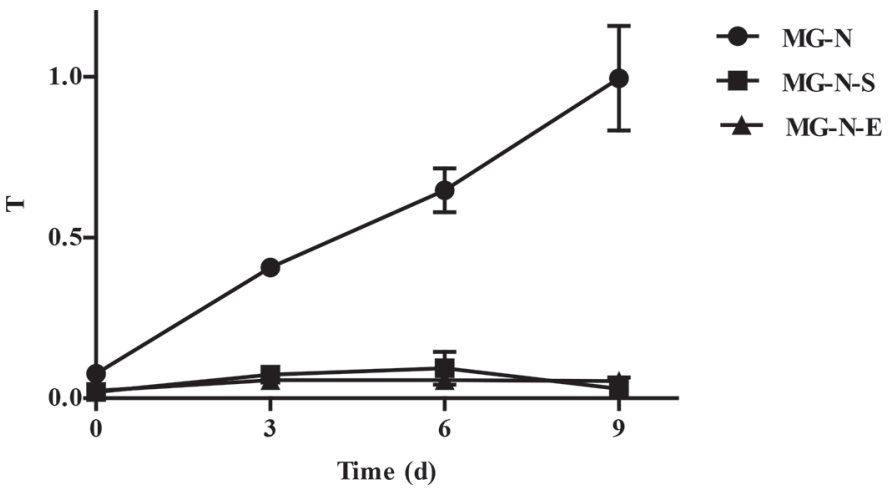

Figure 4. Microbial growth (mean $\pm \mathrm{SD}$ ) in cantaloupe juice (MG) model during storage at $4^{\circ} \mathrm{C}$ for $9 \mathrm{~d}$. MG-N $=0.002 \%$ nisin; MG-N-S $=0.002 \%$ nisin and $3 \%$ soybean protein; $\mathrm{MG}-\mathrm{N}-\mathrm{E}=0.002 \%$ nisin and $2 \%$ egg white protein. The total viable count $(\mathrm{cfu} / \mathrm{mL})$ of control and treatment groups of the cantaloupe juice model were designated $T_{0}$ and $\mathrm{T}_{1}$, respectively, and $\mathrm{T}=\mathrm{T}_{1} / \mathrm{T}_{0}$.

Province (2017GGJS009). The authors have not stated any conflicts of interest.

\section{REFERENCES}

Aasen, I. M., S. Markussen, T. Møretrø, T. Katla, L. Axelsson, and K. Naterstad. 2003. Interactions of the bacteriocins sakacin P and nisin with food constituents. Int. J. Food Microbiol. 87:35-43. https: //doi.org/10.1016/S0168-1605(03)00047-3.

Abdollahzadeh, E., M. Rezaei, and H. Hosseini. 2014. Antibacterial activity of plant essential oils and extracts: The role of thyme essential oil, nisin, and their combination to control Listeria monocytogenes inoculated in minced fish meat. Food Control 35:177-183. https://doi.org/10.1016/j.foodcont.2013.07.004.

Balasubramanian, A., D. S. Lee, M. L. Chikindas, and K. L. Yam. 2011. Effect of nisin's controlled release on microbial growth as modeled for Micrococcus luteus. Probiotics Antimicrob. Proteins 3:113-118. https://doi.org/10.1007/s12602-011-9073-8.

Chang, R., H. Lu, M. Li, S. Zhang, L. Xiong, and Q. Sun. 2018. Preparation of extra-small nisin nanoparticles for enhanced antibacterial activity after autoclave treatment. Food Chem. 245:756-760. https://doi.org/10.1016/j.foodchem.2017.11.116.

Chen, X., S. He, L. Long, L. Huan, and Y. Xue. 1996. Studies on purification and some properties of nisin from Lactococcus lactis ssp. lactis Al2. Acta Microbiol. Sin. 36:269-275.

Chollet, E., I. Sebti, A. Martial-Gros, and P. Degraeve. 2008. Nisin preliminary study as a potential preservative for sliced ripened cheese: $\mathrm{NaCl}$, fat and enzymes influence on nisin concentration and its antimicrobial activity. Food Control 19:982-989. https:// doi.org/10.1016/j.foodcont.2007.10.005.

Fang, W., L. Cao, and S. Hu. 2007. A rapid and accurate 3-(4,5-dimethyl thiazol-2-yl)-2,5-diphenyl tetrazolium bromide colorimetric assay for quantification of bacteriocins with nisin as an example. J. Zhejiang Univ. Sci. B 8:549-554.

Felicio, B. A., M. S. Pinto, F. S. Oliveira, M. W. Lempk, A. C. Pires, and C. A. Lelis. 2015. Effects of nisin on Staphylococcus aureus count and physicochemical properties of Minas Frescal cheese. J. Dairy Sci. 98:4364-4369. https://doi.org/10.3168/jds.2015-9520.

Gruskiene, R., T. Krivorotova, and J. Sereikaite. 2017. Nisin-loaded pectin and nisin-loaded pectin-inulin particles: Comparison of their proteolytic stability with free nisin. Lebensm. Wiss. Technol. 82:283-286. https://doi.org/10.1016/j.lwt.2017.04.061.

He, H., X. Li, X. Kong, Y. Hua, and Y. Chen. 2017. Heat-induced inactivation mechanism of soybean Bowman-Birk inhibitors. Food 
Chem. 232:712-720. https://doi.org/10.1016/j.foodchem.2017.04 .061 .

Holcapkova, P., A. Hurajova, P. Bazant, M. Pummerova, and V. Sedlarik. 2018. Thermal stability of bacteriocin nisin in polylactidebased films. Polym. Degrad. Stabil. 158:31-39. https://doi.org/10 .1016/j.polymdegradstab.2018.10.019.

Huot, E., C. Barrena-Gonzalez, and H. Petitdemange. 1996. Comparative effectiveness of nisin and bacteriocin J46 at different $\mathrm{pH}$ values. Lett. Appl. Microbiol. 22:76-79. https://doi.org/10.1111/j .1472-765X.1996.tb01112.x.

Jozala, A. F., L. C. de Lencastre Novaes, P. G. Mazzola, L. OliveiraNascimento, T. C. Vessoni Penna, J. A. Teixeira, L. A. Passarinha, J. A. Queiroz, and A. Pessoa. 2015. Low-cost purification of nisin from milk whey to a highly active product. Food Bioprod. Process. 93:115-121. https://doi.org/10.1016/j.fbp.2013.12.003.

Ko, K. Y., S. R. Park, C. A. Lee, and M. Kim. 2015. Analysis method for determination of nisin $\mathrm{A}$ and nisin $\mathrm{Z}$ in cow milk by using liquid chromatography-tandem mass spectrometry. J. Dairy Sci. 98:1435-1442. https://doi.org/10.3168/jds.2014-8452.

Luo, L., Y. Wu, C. Liu, L. Huang, Y. Zou, Y. Shen, and Q. Lin. 2019. Designing soluble soybean polysaccharides-based nanoparticles to improve sustained antimicrobial activity of nisin. Carbohydr. Polym. 225:115251. https://doi.org/10.1016/j.carbpol.2019 .115251 .

Muranova, T. A., D. V. Zinchenko, N. A. Belova, A. K. Surin, and A. I. Miroshnikov. 2019. Soybean trypsin inhibitors: Selective inactivation at hydrolysis of soybean proteins by some enzymatic complexes. Appl. Biochem. Micro+ 55:270-276.

National Standard of China. 2009. GB/T 23527-2009. Protease preparation. Accessed Jan. 29, 2020. https://www.chinesestandard.net/ PDF/English.aspx/GBT23527-2009.

National Standard of China. 2010. GB4789.2-2010. The total viable count (TVC) is determined in the microbiology of food hygiene. Accessed Jan. 29, 2020. https://www.chinesestandard.net/PDF/ Sample.aspx/GB4789.2-2010.

Norioka, N., S. Hara, T. Ikenaka, and J. Abe. 2006. Distribution of the Kunitz and the Bowman-Birk family proteinase inhibitors in leguminous seeds. Agric. Biol. Chem. 52:1245-1252.

Ødum, L. 1987. Trypsin-inhibitory activity of ovalbumin preparations is due to ovomucoid. Biol. Chem. Hoppe Seyler 368:1603-1606. https://doi.org/10.1515/bchm3.1987.368.2.1603.

Oshima, S., A. Hirano, H. Kamikado, J. Nishimura, Y. Kawai, and T. Saito. 2014. Nisin A extends the shelf life of high-fat chilled dairy dessert, a milk-based pudding. J. Appl. Microbiol. 116:1218-1228. https://doi.org/10.1111/jam.12454.
Pawar, D. D., S. V. S. Malik, K. N. Bhilegaonkar, and S. B. Barbuddhe. 2000. Effect of nisin and its combination with sodium chloride on the survival of Listeria monocytogenes added to raw buffalo meat mince. Meat Sci. 56:215-219. https://doi.org/10.1016/S0309 $-1740(00) 00043-7$.

Rackis, J. J., W. J. Wolf, and E. C. Baker. 1986. Protease inhibitors in plant foods: Content and inactivation. Adv. Exp. Med. Biol. 199:299-347. https://doi.org/10.1007/978-1-4757-0022-0_19.

Rahman, S. M. E., J. Wang, and D.-H. Oh. 2013. Synergistic effect of low concentration electrolyzed water and calcium lactate to ensure microbial safety, shelf life and sensory quality of fresh pork. Food Control 30:176-183. https://doi.org/10.1016/j.foodcont.2012 .06 .041 .

Salman, K. 2011. Characterization of an avian protease inhibitor. Bioresour. Technol. 1:58-68.

Sarkar, P., A. K. Bhunia, and Y. Yao. 2016. Emulsion stabilized with starch octenyl succinate prolongs nisin activity against Listeria monocytogenes in a cantaloupe juice model. J. Food Sci. 81:M2982M2987. https://doi.org/10.1111/1750-3841.13550.

Sarkar, P., A. K. Bhunia, and Y. Yao. 2017. Impact of starch-based emulsions on the antibacterial efficacies of nisin and thymol in cantaloupe juice. Food Chem. 217:155-162. https://doi.org/10.1016/j foodchem.2016.08.071.

Shi, C., X. Zhang, X. Zhao, R. Meng, Z. Liu, X. Chen, and N. Guo. 2017. Synergistic interactions of nisin in combination with cinnamaldehyde against Staphylococcus aureus in pasteurized milk. Food Control 71:10-16. https://doi.org/10.1016/j.foodcont.2016.06.020.

Slootweg, J. C., R. M. Liskamp, and D. T. Rijkers. 2013. Scalable purification of the lantibiotic nisin and isolation of chemical/enzymatic cleavage fragments suitable for semi-synthesis. J. Pept. Sci. 19:692-699. https://doi.org/10.1002/psc.2551.

Wu, T., C. Wu, Z. Fang, X. Ma, S. Chen, and Y. Hu. 2017. Effect of chitosan microcapsules loaded with nisin on the preservation of small yellow croaker. Food Control 79:317-324. https://doi.org/10 .1016/j.foodcont.2017.04.016.

Yuan, J., Z. Z. Zhang, X. Z. Chen, W. Yang, and L. D. Huan. 2004. Site-directed mutagenesis of the hinge region of nisinZ and properties of nisinZ mutants. Appl. Microbiol. Biotechnol. 64:806-815. https://doi.org/10.1007/s00253-004-1599-1.

\section{ORCIDS}

Dan Pan • https://orcid.org/0000-0003-1605-9149

Jike Lu (ㄴ https://orcid.org/0000-0001-9339-4835 